\title{
Professional Learning Communities: A Comparative Study of Three Educational Areas in the North West Province of South Africa
}

\author{
D. Nkengbeza, J. Heystek \\ Educational Foundations and Management, University of Namibia, Katima Mulilo Campus, Katima Mulilo, Namibia \\ Email: dnkengbeza@gmail.com
}

How to cite this paper: Nkengbeza, D. and Heystek, J. (2017) Professional Learning Communities: A Comparative Study of Three Educational Areas in the North West Province of South Africa. Open Journal of Social Sciences, 5, 98-119.

https://doi.org/10.4236/jss.2017.54010

Received: March 1, 2017

Accepted: April 18, 2017

Published: April 21, 2017

Copyright (c) 2017 by authors and Scientific Research Publishing Inc. This work is licensed under the Creative Commons Attribution International License (CC BY 4.0).

http://creativecommons.org/licenses/by/4.0/

\begin{abstract}
Even though South African policy makers and implementers have done a lot to improve education especially in rural areas and townships, much more thinking and policy direction still need to be done to improve education in these areas. The purpose of this article is to compare the perception of teachers and principals of their schools as professional learning communities in three educational areas in the North West Province of South Africa. A quantitative research method was used and questionnaires were used to collect data from schools in these three areas. 1251 teachers and principals were involved in this research. The major findings were: there were no major differences between the three areas in teachers' and principals' perception of their schools as PLCs, but there were major differences between schools in urban centers, townships and rural areas. This study has reiterated the fact that the South African government needs to rethink how to readdress education and social needs in rural and township schools, as the current policies have not completely addressed the disparities between schools in rural areas, townships and urban centers.
\end{abstract}

\section{Keywords}

Professional Learning Communities, Shared Supportive Leadership, Collective Creativity, Shared Values and Vision, Townships, Comparative Study

\section{Introduction}

As South African education policy makers and nation builders continue to improve school performance in the country, a lingering problem is the disparity between schools in urban centres, townships and rural areas including farm schools and others. The problems facing rural and township schools are many 
and diverse, yet our "one size fits all" education policies and implementation to some extent have failed to effectively address the problems of these schools [1]. This article compares the perception of teachers and principals of their schools as professional learning communities in three educational areas in the North West Province of South Africa. The main findings are specific: there are no major differences between schools in the three areas, but when we compared schools in urban areas, townships and rural areas, there were major differences. In reporting and interpreting our findings, both the substantive significant (effect size) and the p-values have been presented [2].

\subsection{Research Problem}

In South Africa, accountability for school improvement has led many educational stakeholders to search for ways to improve students' performances. This has led to the establishment of professional learning communities in schools because of its tremendous contributions in improving students learning [3] [4]. There has not been a lot of focus in South Africa on the perception of teachers and principals of their school as professional learning communities. This article will help to cover this gap.

This article is a reminder to the policy makers and those involved in education management and leadership that the problems faced by rural and township schools are real and are not being addressed properly with our current education policies. In order to better handle the problems and transform schools into professional learning communities, everyone from grade level teams to the top officials in the ministry of education, including policy makers and teachers training institutions, must continue to work together for the success of transforming schools in rural areas, townships and urban centres into professional learning communities.

\subsection{The Purpose of the Research and Research Questions}

The purpose of this research is to compare teachers' and principals' perception of their schools as professional learning communities (PLCs) in the three areas. The research questions are:

1) What is the perception of teachers and principals in the three areas of their schools as PLCs?

2) How are teachers' and principals' perceptions of schools as PLCs in urban towns different from those in rural and townships?

3) How are teachers and principals in different types of schools (primary, combined etc.) different from each other in terms of the perception of their schools as PLCs?

\section{The Conceptual Framework of PLCs}

Professional learning communities are inclusive education institutions that continuously and collectively question the status quo and seek for better means to improve their institutions [5] — what Hord [6] called "Communities of continu- 
ous enquiry and improvement". The conceptual framework for this study is depicted on Figure 1 below.

The conceptual framework for this study as shown on figure one above includes shared supportive leadership, collective creativity, shared values and vision, supportive conditions and shared personal practice [2] [5] [7] [8] [9] [10]. Each of these core components is explained briefly below.

\subsection{Supportive Shared Leadership}

The principal is at the centre of every professional learning community. The principal, in order to develop and sustain a school as a professional learning community, must share power, authority and decision making among all the stakeholders in the school [8] [9] [10]. Sharing or delegating duties may be really problematic in societies where teachers are given a specific number of hours per week by labour laws [11]. The trade union of education in Finland contributes in the development of education and ensures that teachers are given overtime for additional duties [2] [11]. The staff of every school must create a collegial environment, work together as a team and view each other as peers and colleagues. Principals are therefore in the middle of a change process in their schools [2].

\subsection{Collective Creativity}

For collective creativity to take place, there must be "open practice ... that encourages sharing, reflecting, and taking the risk necessary" for change to take place [12]. Webb, Vulliamy, Sarja, Hamallainen, and Poikonen [11] have concluded that working in teams, sharing concerns and solving problems improve teachers' moral and effectiveness, and are "key factor[s] in teachers' retention".

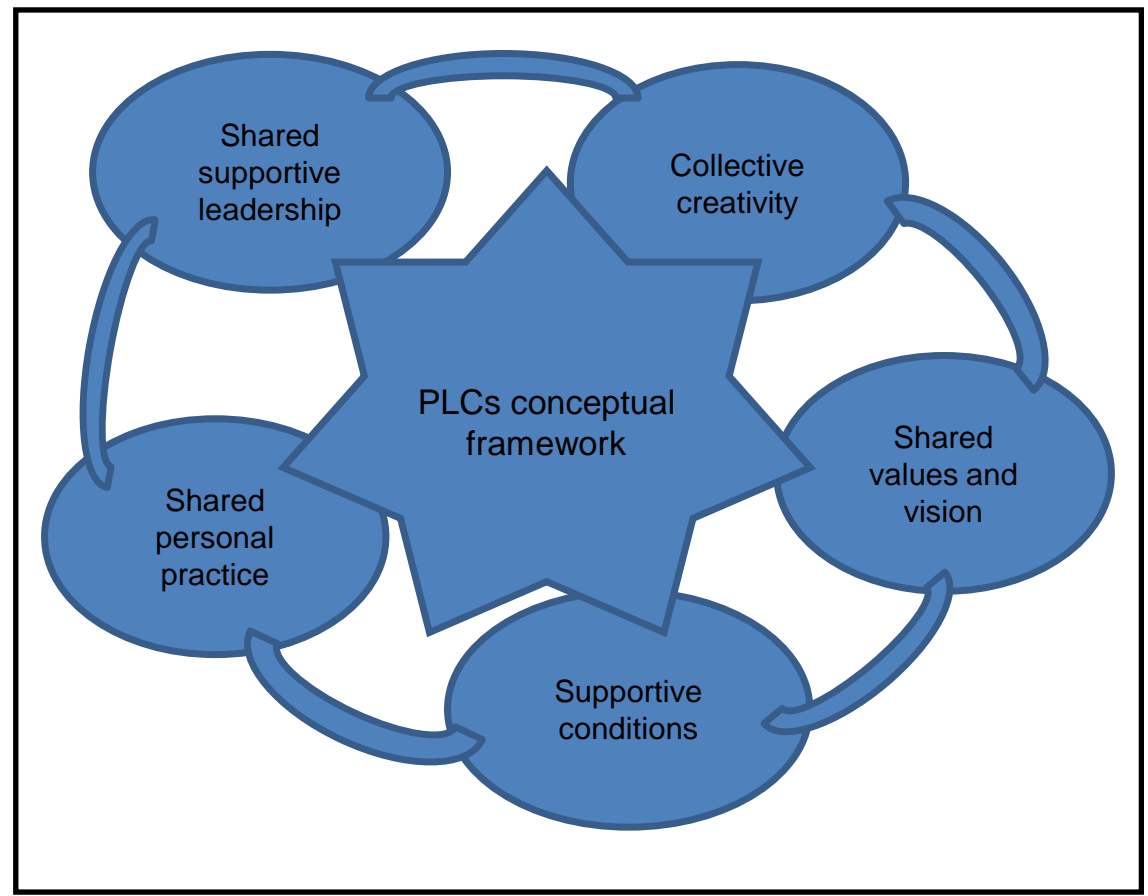

Figure 1. The conceptual framework of PLCs. 
They have further argued that lack of time, financial cost, distance between schools, and lack of teachers' commitment are barriers to collective learning between schools. Good collaboration and trust among the stakeholders are necessary for collective learning to take place. Collective enquiry helps every school and its staffs to better handle its problems and focus on its vision and the school transformation process [2] [9].

\subsection{Shared Values and Vision}

Vision is very important in the creation and sustaining of every school as a professional learning community. While Huffman [13] has argued that administrators should base their vision on shared values in order to lead their schools through reforms, Hunter [14] believes that certain "core principles must be established as non-negotiable" for the PLC to succeed. According to Hunter [14], a visionary principal must be a change agent, spokesperson and a mentor in order to lead a professional learning community. The creation of a good shared vision must be based on shared values and beliefs, and supported by the entire staff [9] [10].

\subsection{Supportive Conditions}

Supportive conditions are usually in the form of physical conditions, like time and place to meet and talk, "teacher empowerment and shared autonomy" or people's capacity, including the willingness to receive feedback and work towards improvement [5] [9]. This idea has also been echoed by other researchers like Hord [8], that there should be available time for learning, available space where the whole staff can meet and of course there should also be mentoring by the senior staff and other specialists. It is also crucial that the teachers are provided with the necessary teaching materials and the necessary environment for learning to take place.

\subsection{Shared Personal Practice}

According to Hord [8] peer sharing practice that enriches feedback leads to individual and organisational development. In a professional learning community every individual must have the "responsibility to share [his/her] personal practice and provide support" to each other [15]. Nkengbeza [2] [5] [9] believes that it is the duty of every school leadership to challenge teachers to share and develop structures that lead to student learning and enables the whole faculty to succeed. The development of information and communication technologies (ICT) has made easier the sharing of personal practice by teachers both nationally and internationally [9].

\section{Research Methodology}

\subsection{Quantitative Method}

A quantitative research method deals with the collection of "quantifiable data from participants, [and] analyse these numbers using statistics" [15]. The statis- 
tical analysis involves "describing trends, comparing group differences, or relating group variables" [15]. We decided to use quantitative research methods because we wanted to compare teachers and principals' assessment of their schools in three areas as professional learning communities. In order to be able to generalise our findings in the three areas, we had to get our responses from more than a thousand teachers and principals.

\subsection{Data Collection Method-Questionnaires}

Questionnaires (See Appendixes) were used to collect data for this research. These questionnaires were constructed using the core components of professional learning communities as used by Nkengbeza [2] [5] and other researchers like Lee et al. [7]. These core components have been explained in the conceptual framework. Section "A" of the questionnaires consisted of respondents' personal information and the schools' details. Section "B" consisted of 71 questions/ statements on the core components of professional learning communities. We used the Likert Scale from 1 to 4 (Scale: 1. = Strongly Agree [SA], 2. = Agree [A], 3. $=$ Disagree $[D]$, and 4. $=$ Strongly Disagree $[S D]$ ) [2]. The questionnaires were given to all the schools in the three areas in a district in the North West Province of South Africa. The total numbers of returned questionnaires within forty days were as follows: Area One 294, Area Two 657 and Area Three 300 (1251). Many principals explained that the teachers were very busy preparing for their final examination.

\subsection{Validity and Reliability of This Research}

While research validity is the degree of consistency that your research process demonstrates, research reliability is the quality of your data gathering instrument [16]. According to Best and Kahn [16] validity is "the degree to which evidence and theory support the interpretation". In this research there has been content validity, where principals and teachers have assessed themselves/their schools using the questionnaires derived from the core component of professional learning communities. The questionnaires were valid and a similar questionnaire had been used by previous researchers like Olivier, Antoine, Cormier, Lewis, Minckler and Stadalis [2] [17]. These valid questionnaires have enabled us to compare teachers and principals' perception of their schools as professional learning communities in the three areas. The measurement mechanisms in this study, from data collection to findings and conclusion, are quite reliable. The Cronbach's Alpha for every core component is more than 0.80 which, according to Hair, Anderson, Tatham and Black [18], is excellent. However, Thompson [19] has rightly explained that, because total score variance is an important aspect of reliability, the participants involved in the study may themselves affect score reliability in a situation where the same measure are administered to more heterogeneous or more homogenous sets of subjects.

Cronbach's Alpha reliability coefficient for Area 1, 2 and 3

The Cronbach's Alphain the three Areas, as it can be seen in Table 1, is 
Table 1. The Cronbach's Alpha reliability coefficient for Area 1, 2 and 3, and the core components of PLCs.

\begin{tabular}{cccccccc}
\hline Area & $\begin{array}{c}\text { Shared } \\
\text { supportive } \\
\text { leadership }\end{array}$ & $\begin{array}{c}\text { Collective } \\
\text { creativity }\end{array}$ & $\begin{array}{c}\text { Shared } \\
\text { values } \\
\text { and vision }\end{array}$ & $\begin{array}{c}\text { Shared } \\
\text { personal } \\
\text { practice }\end{array}$ & $\begin{array}{c}\text { Supportive } \\
\text { conditions- } \\
\text { relationship }\end{array}$ & $\begin{array}{c}\text { Supportive } \\
\text { conditions- } \\
\text { structures }\end{array}$ & $\begin{array}{c}\text { Additional } \\
\text { statements }\end{array}$ \\
\hline 1 & 0.93 & 0.91 & 0.94 & 0.91 & 0.90 & 0.85 & 0.90 \\
2 & 0.93 & 0.92 & 0.88 & 0.90 & 0.85 & 0.85 & 0.87 \\
3 & 0.94 & 0.93 & 0.92 & 0.89 & 0.84 & 0.87 & 0.89 \\
\hline
\end{tabular}

greater than 0.80 and according to Hair, Anderson, Tatham and Black [18], it is extremely good. According to George and Mallery [20] Cronbach Alpha is interpreted as follows:

$$
\begin{aligned}
& \geq 0.9=\text { Excellent } \\
& \geq 0.8=\text { Good }, \\
& \geq 0.7=\text { Acceptable, } \\
& \geq 0.6=\text { Questionable, } \\
& \geq 0.5=\text { Poor, and } \\
& <0.5=\text { Unacceptable [2] [20]. }
\end{aligned}
$$

We should note that a high value for Cronbach's alpha in each of the core components indicates good internal consistency of the items in the scale as shown in Table 1.

\subsection{Ethical Consideration of the Study}

This research project was approved by the North West University Ethics Committee. We were also granted the permission to carry out the research by the department of education. The three Area education managers were also well-informed about the research and they helped in the delivering of the questionnaires to the respective schools in their areas. The names of the participants in this research have not been revealed. Also, the names of the areas and other authorities have been kept anonymous. Consent letters were sent to all the principals, teachers and the school governing board chair person in every school. The letters informed the respective individuals about the research and asked them to sign and return the consent forms together with the questionnaires. Another letter to the principals gave them a step-by-step direction on how to distribute the questionnaires, collect and return the completed questionnaires. All participants were informed that their participation was voluntary, with no remuneration of any kind.

\section{Data Analysis and Presentation}

The data for this research were analysed using SPSS (factor analysis and reliability, descriptive statistics, t-tests and ANOVA), as suggested by Field [21]. The data are presented on five main tables. Tables 2-4 compare teachers' and principals' perceptions of their schools as PLCs in Area 1,2 and 3. Table 5 compares teachers' and principals' perceptions of schools in townships, urban towns, and 
Table 2. Shared supportive leadership, collective creativity, shared values and vision, and shared personal practice.

\begin{tabular}{|c|c|c|c|}
\hline \multicolumn{4}{|c|}{ Shared supportive leadership } \\
\hline Scale & Area 1 & Area 2 & Area 3 \\
\hline Strongly Agree & $30 \%$ & $27 \%$ & $29 \%$ \\
\hline Agree & $56 \%$ & $56 \%$ & $58 \%$ \\
\hline Disagree & $11 \%$ & $13 \%$ & $11 \%$ \\
\hline Strongly Disagree & $2 \%$ & $4 \%$ & $3 \%$ \\
\hline \multicolumn{4}{|c|}{ Collective creativity } \\
\hline Scale & Area 1 & Area 2 & Area 3 \\
\hline Strongly Agree & $31 \%$ & $26 \%$ & $26 \%$ \\
\hline Agree & $55 \%$ & $58 \%$ & $61 \%$ \\
\hline Disagree & $12 \%$ & $14 \%$ & $12 \%$ \\
\hline Strongly Disagree & $2 \%$ & $2 \%$ & $2 \%$ \\
\hline \multicolumn{4}{|c|}{ Shared values and vision } \\
\hline Scale & Area 1 & Area 2 & Area 3 \\
\hline Strongly Agree & $33 \%$ & $25 \%$ & $25 \%$ \\
\hline Agree & $57 \%$ & $64 \%$ & $65 \%$ \\
\hline Disagree & $8 \%$ & $10 \%$ & $8 \%$ \\
\hline Strongly Disagree & $1 \%$ & $2 \%$ & $1 \%$ \\
\hline \multicolumn{4}{|c|}{ Shared personal practice } \\
\hline Scale & Area 1 & Area 2 & Area 3 \\
\hline Strongly Agree & $32 \%$ & $24 \%$ & $27 \%$ \\
\hline Agree & $58 \%$ & $63 \%$ & $64 \%$ \\
\hline Disagree & $9 \%$ & $11 \%$ & $7 \%$ \\
\hline Strongly Disagree & $1 \%$ & $2 \%$ & $2 \%$ \\
\hline
\end{tabular}

rural areas using the seven core components of professional learning communities. Finally, Table 6 compares teachers' and principals' perception of their schools as professional learning communities under primary, combined, intermediate and secondary schools. The Cronbach's Alpha for the core components in Area 1, 2 and 3 is shown on table one (under validity and reliability of this research).

The following section compares the respondents' perception of their schools as professional learning communities in Area 1,2 and 3, under the core components of shared supportive leadership, collective creativity, shared values and 
Table 3. Supportive conditions-relationships, supportive conditions-structures, and additional statements.

\begin{tabular}{cccc}
\hline \multicolumn{4}{c}{ Supportive conditions-relationships } \\
\hline Scale & Area 1 & Area 2 & Area 3 \\
\hline Strongly Agree & $34 \%$ & $26 \%$ & $27 \%$ \\
Agree & $53 \%$ & $59 \%$ & $61 \%$ \\
Disagree & $11 \%$ & $13 \%$ & $10 \%$ \\
Strongly Disagree & $2 \%$ & $2 \%$ & $3 \%$ \\
\hline & Supportive conditions-structures & \\
\hline Scale & Area 1 & Area 2 & Area 3 \\
\hline Strongly Agree & $27 \%$ & $19 \%$ & $20 \%$ \\
Agree & $51 \%$ & $56 \%$ & $59 \%$ \\
Disagree & $17 \%$ & $19 \%$ & $15 \%$ \\
Strongly Disagree & $5 \%$ & $6 \%$ & $6 \%$ \\
\hline & & & \\
\hline Scale & Additional statements & & $1 \%$ \\
\hline Strongly Agree & Area 1 & Area 2 & Area 3 \\
Agree & $30 \%$ & $19 \%$ & $24 \%$ \\
Disagree & $60 \%$ & $67 \%$ & $67 \%$ \\
\hline Strongly Disagree & $9 \%$ & $12 \%$ & $8 \%$ \\
\hline
\end{tabular}

Table 4. Mixed model analysis for principals/teachers in Area 1, 2 and 3 compared.

\begin{tabular}{|c|c|c|c|c|c|c|c|}
\hline & Area 1 & Area 2 & Area 3 & & p-valu & & Effect size \\
\hline PLCs components & $\begin{array}{c}\text { Principal/ } \\
\text { teacher mean }\end{array}$ & $\begin{array}{c}\text { Principal/ } \\
\text { teacher mean }\end{array}$ & $\begin{array}{c}\text { Principal/ } \\
\text { teacher mean }\end{array}$ & Area & $\begin{array}{l}\text { Principal- } \\
\text { teacher }\end{array}$ & Interaction & $\begin{array}{l}\text { Prin./tea \& } \\
\text { Area } 1,2,3\end{array}$ \\
\hline $\begin{array}{l}\text { Shared Supportive } \\
\text { leadership }\end{array}$ & 1.788 & 1.831 & 1.778 & 0.795 & 0.002 & 0.810 & $\begin{array}{l}\text { A1 \& } 2.09 \\
\text { A1 \& } 3.02 \\
\text { A2 \& } 3.11\end{array}$ \\
\hline Collective creativity & 1.886 & 1.872 & 1.777 & 0.426 & 0.043 & 0.141 & $\begin{array}{l}\text { A1 \& } 2.03 \\
\text { A1 \& } 3.24 \\
\text { A2 \& } 3.21\end{array}$ \\
\hline $\begin{array}{l}\text { Shared values } \\
\text { and vision }\end{array}$ & 1.767 & 1.875 & 1.753 & 0.254 & 0.059 & 0.358 & $\begin{array}{l}\text { A1 \& } 2.23 \\
\text { A1 \& } 3.03 \\
\text { A2 \& } 3.26\end{array}$ \\
\hline $\begin{array}{l}\text { Shared personal } \\
\text { practice }\end{array}$ & 1.805 & 1.905 & 1.713 & 0.090 & 0.125 & 0.194 & $\begin{array}{l}\text { A1 \& } 2.21 \\
\text { A1 \& } 3.19 \\
\text { A2 \& } 3.39\end{array}$ \\
\hline $\begin{array}{l}\text { Supportive conditions } \\
\text { - relationships }\end{array}$ & 1.823 & 1.909 & 1.772 & 0.304 & 0.146 & 0.263 & $\begin{array}{l}\text { A1 \& } 2.17 \\
\text { A1 \& } 3.10 \\
\text { A2 \& } 3.27\end{array}$ \\
\hline $\begin{array}{l}\text { Supportive conditions } \\
\text { - structures }\end{array}$ & 2.064 & 2.130 & 1.968 & 0.244 & 0.204 & 0.222 & $\begin{array}{l}\text { A1 \& } 2.13 \\
\text { A1 \& } 3.18 \\
\text { A2 \& } 3.31\end{array}$ \\
\hline Additional statements & 1.810 & 1.973 & 1.797 & 0.091 & 0.182 & 0.623 & $\begin{array}{l}\text { A1 \& } 2.32 \\
\text { A1 \& } 3.02 \\
\text { A2 \& } 3.34\end{array}$ \\
\hline
\end{tabular}


Table 5. Mixed model analysis for schools in Township, Town (Urban) and Rural Areas compared.

\begin{tabular}{|c|c|c|c|c|c|c|c|}
\hline School location & Township (Ts) & Town Urban (Tu) & Rural (R) & & p-valu & & Effect size \\
\hline PLCs components & $\begin{array}{c}\text { Principal \& } \\
\text { Teacher mean }\end{array}$ & $\begin{array}{c}\text { Principal \& } \\
\text { Teacher mean }\end{array}$ & $\begin{array}{c}\text { Principal \& } \\
\text { Teacher mean }\end{array}$ & Area & $\begin{array}{l}\text { Principal } \\
\text {-Teacher }\end{array}$ & Interaction & $\begin{array}{c}\text { Principal } \\
\text { with Teacher }\end{array}$ \\
\hline $\begin{array}{l}\text { Shared Supportive } \\
\text { leadership }\end{array}$ & 1.899 & 1.694 & 1.863 & 0.133 & 0.022 & 0.224 & $\begin{array}{l}\text { Tu \& Ts } 0.42 \\
\text { Tu \& R } 0.35 \\
\text { R \& Ts } 0.08\end{array}$ \\
\hline Collective creativity & 1.965 & 1.749 & 1.920 & 0.015 & 0.007 & 0.028 & $\begin{array}{l}\text { Tu \& Ts } 0.47 \\
\text { Tu \& R } 0.37 \\
\text { R \& Ts } 0.10\end{array}$ \\
\hline $\begin{array}{l}\text { Shared values } \\
\text { and vision }\end{array}$ & 1.937 & 1.726 & 1.837 & 0.060 & 0.040 & 0.248 & $\begin{array}{l}\text { Tu \& Ts } 0.45 \\
\text { Tu \& R } 0.24 \\
\text { R \& Ts } 0.21\end{array}$ \\
\hline $\begin{array}{l}\text { Shared personal } \\
\text { practice }\end{array}$ & 1.942 & 1.779 & 1.809 & 0.119 & 0.062 & 0.190 & $\begin{array}{l}\text { Tu \& Ts } 0.33 \\
\text { Tu \& R } 0.06 \\
\text { R \& Ts } 0.27\end{array}$ \\
\hline $\begin{array}{l}\text { Supportive conditions } \\
\text { - relationships }\end{array}$ & 1.993 & 1.756 & 1.902 & 0.013 & 0.028 & 0.102 & $\begin{array}{l}\text { Tu \& Ts } 0.47 \\
\text { Tu \& R } 0.29 \\
\text { R \& Ts } 0.18\end{array}$ \\
\hline $\begin{array}{l}\text { Supportive conditions } \\
\text { - structures }\end{array}$ & 2.154 & 1.931 & 2.176 & 0.062 & 0.222 & 0.437 & $\begin{array}{l}\text { Tu \& Ts } 0.43 \\
\text { Tu \& R } 0.47 \\
\text { R \& Ts } 0.04\end{array}$ \\
\hline Additional statements & 1.998 & 1.780 & 1.907 & 0.101 & 0.087 & 0.554 & $\begin{array}{l}\text { Tu \& Ts } 0.42 \\
\text { Tu \& R } 0.25 \\
\text { R \& Ts } 0.17\end{array}$ \\
\hline
\end{tabular}

Table 6. Mixed model analysis for primary, combine, intermediate and secondary schools compared.

\begin{tabular}{|c|c|c|c|c|c|c|c|c|}
\hline Level of school & Primary & Combine & Intermediate & & Secondary & $\mathrm{p}$-value & & Effect size \\
\hline $\begin{array}{c}\text { PLCs } \\
\text { components }\end{array}$ & $\begin{array}{c}\text { Principal/ } \\
\text { Teacher mean }\end{array}$ & $\begin{array}{c}\text { Principal/ } \\
\text { Teacher mean }\end{array}$ & $\begin{array}{c}\text { Principal/ } \\
\text { Teacher mean }\end{array}$ & $\begin{array}{c}\text { Principal/ } \\
\text { Teacher mean }\end{array}$ & $\begin{array}{c}\text { School } \\
\text { level }\end{array}$ & $\begin{array}{l}\text { Principal } \\
\text {-Teacher }\end{array}$ & Interaction & $\begin{array}{c}\text { Principal } \\
\text { with Teacher }\end{array}$ \\
\hline $\begin{array}{l}\text { Shared } \\
\text { Supportive } \\
\text { leadership }\end{array}$ & 1.738 & 1.990 & 1.716 & 1.977 & 0.047 & 0.313 & 0.899 & $\begin{array}{l}P \& C 0.53 \\
P \& S 0.50 \\
C \& I 0.57 \\
I \& S 0.55\end{array}$ \\
\hline $\begin{array}{l}\text { Collective } \\
\text { creativity }\end{array}$ & 1.793 & 2.158 & 1.895 & 2.003 & 0.013 & 0.249 & 0.359 & $\begin{array}{l}\text { P \& C } 0.81 \\
\text { P \& S } 0.46 \\
\text { C \& I } 0.58\end{array}$ \\
\hline $\begin{array}{c}\text { Shared values } \\
\text { and vision }\end{array}$ & 1.734 & 2.024 & 1.996 & 1.969 & 0.014 & 0.318 & 0.906 & $\begin{array}{l}P \& C 0.63 \\
P \& I 0.57 \\
P \& S 0.51\end{array}$ \\
\hline $\begin{array}{l}\text { Shared } \\
\text { personal } \\
\text { practice }\end{array}$ & 1.747 & 2.111 & 1.811 & 2.022 & 0.004 & 0.420 & 0.647 & $\begin{array}{l}\text { P \& C } 0.77 \\
\text { P \& S } 0.58 \\
\text { C \& I } 0.63 \\
\text { I \& S } 0.44\end{array}$ \\
\hline $\begin{array}{l}\text { Supportive } \\
\text { conditions - } \\
\text { relationships }\end{array}$ & 1.764 & 2.032 & 2.023 & 2.051 & 0.002 & 0.308 & 0.430 & $\begin{array}{l}\text { P \& C } 0.55 \\
\text { P \& I } 0.53 \\
P \& S 0.58\end{array}$ \\
\hline $\begin{array}{l}\text { Supportive } \\
\text { conditions } \\
\text { - structures }\end{array}$ & 1.987 & 2.271 & 2.091 & 2.229 & 0.086 & 0.604 & 0.854 & $\begin{array}{l}P \& \text { \& } 0.55 \\
P \& S 0.47\end{array}$ \\
\hline $\begin{array}{l}\text { Additional } \\
\text { statements }\end{array}$ & 1.808 & 1.998 & 1.802 & 2.061 & 0.041 & 0.191 & 0.376 & $\begin{array}{l}P \& S 0.49 \\
I \& S 0.50\end{array}$ \\
\hline
\end{tabular}


vision, shared personal practice, supportive conditions-relationships, supportive conditions-structures, and additional statements-other statements which support the building of PLCs.

PLCs core components analysis of Area 1, $2 \& 3$ (Shared supportive leadership, collective creativity, shared values and vision, and shared personal practice)

Table 2 shows that the majority of respondents (55\% or more) in the three areas "agree" with the statements on the core components of professional learning communities. The majority of those who "strongly agree" in the core component of shared supportive leadership, collective creativity, shared values and vision and shared personal practice, are from Area one.

PLCs core components analysis of Area 1, $2 \& 3$ (Supportive conditions and additional statements)

From Table 3, it can be seen that the majority of respondents (51\% or more) "agree" with the statements on the core components of professional learning communities of supportive conditions and additional statements in the three areas. Supportive conditions-structures component has the highest number of respondents who "disagree" or "strongly disagree" with the statements on the above core components of professional learning communities.

\section{Analysis for principals/teachers in Area 1, 2 and 3}

Table 4 compares teachers and principals' perceptions of their schools as PLCs in Area 1, 2 and 3 (Mixed model analysis: fixed effect, co-variance parameters, estimated marginal means \& effect size). The effect size here is the magnitude of the difference between Area one and two, one and three and two and three. The effect sizes between these areas are statistically insignificant or statistically significant with a small effect size in many core components. This confirms that there is no significant difference between schools in the three areas. $\mathrm{A} 1=$ Area one, $\mathrm{A} 2=$ Area two and $\mathrm{A} 3=$ Area three .

Research question 2: How are teachers' and principals' perceptions of schools as PLCs in urban towns different from those in rural areas and townships?

\section{Analysis for schools in Township, Town (Urban) and Rural Areas}

Table 5 compares teachers' and principals' perceptions of schools in townships, urban towns and rural areas using the seven core components of professional learning communities. The effect size here is the magnitude of the difference in teachers' and principals' perceptions of schools in townships and towns-urban and rural areas. The abbreviations for the levels of schools are as follows: $\mathrm{Tu}=$ town-urban, $\mathrm{Ts}=$ townships and $\mathrm{R}=$ rural areas.

Research question 3: How are teachers and principals in different types of schools (primary, combined etc.) different from each other in terms of the perception of their schools as PLCs?

\section{Analysis for primary, combine, intermediate and secondary schools}

Table 6 compares teachers' and principals' perception of their schools as professional learning communities under primary, combined, intermediate and secondary schools. The effect size here is the magnitude of the difference be- 
tween primary schools and other levels of schools using the different components. It should be noted that only the medium (or very close to medium) effect sizes $(0.44-0.49)$ and large effect sizes have been reported. The abbreviations used under the effect size above are as follows: $\mathrm{P}=$ primary schools, $\mathrm{C}=$ combined schools, $\mathrm{I}=$ intermediate schools and $\mathrm{S}=$ secondary schools.

\section{Main Findings}

\subsection{The Perception of Teachers and Principals of Their Schools as PLCs in the Three Areas Compared}

The following section compares teachers' and principals' perception of their schools (Tables 2-4) as PLCs, to answer the above research question. As it can be seen from Table 2 and Table 3, Area one had the highest percentage of respondents who "strongly agreed" with the statements on the core components of professional learning communities in all the core components, compared to Area two and three. On the other hand, the percentages of respondents who "agreed" in Area two and three were higher than those in Area one in almost all the core components.

As it can be seen from Table 4 (Mixed model analysis for Area 1, 2 and 3), principals and teachers in all the three areas perceived their schools as professional learning communities similarly in all the core components. As a result, comparing the three areas reveals statistically insignificant effect sizes or statistically significant but with very small effect sizes in all the core components of professional learning communities (see Table 4).

\subsection{Teachers and Principals' Perception of Schools as PLCs in Urban Towns, Townships, and Rural Areas Compared}

As it can be seen from Table 5, this study has revealed that teachers' and principals' perception of schools as PLCs in Urban Towns is much higher than those in Townships and Rural Areas in all the seven core components. The differences between schools (urban towns, townships, and rural areas) are statistically significant, very close to the medium effect sizes.

Comparing Urban Towns and Rural Areas has also revealed that schools in Urban Towns were rated higher than those in Rural Areas with a statistically significant small effect size in almost all the core components. The perception of teachers and principals of their schools as PLCs was the lowest in Townships' schools compared to those in urban towns and rural areas. Comparing township schools with those in rural areas has revealed that rural schools are rated higher than those in townships but with a statistical insignificant effect size in most of the core components.

\subsection{Teachers and Principals in Different Types of Schools (i.e. Primary, Combined etc.) Perception of Their Schools as PLCs Compared}

As it can be seen on Table 6, teachers' and principals' perception of their schools 
as professional learning communities was highest in primary schools compared to combined, intermediate and secondary schools. The study has also revealed that primary, combined, intermediate and secondary schools are very different from each other. These disparities between various levels of schools are statistically significant with medium effect sizes in most of the core components, especially between primary and other levels of schools. The largest statistical significant (large) effect size is between primary and combined schools in collective creativity component $(0.81)$.

\section{Discussion}

Comparing the three Areas in this study revealed that Area two had the highest number of respondents (657) for both males (192) and females (465). The highest numbers of respondents in the three areas were between the ages of 35 and 55. School location: The schools which took part in this research and choose to identify their locations were evenly distributed: Township-23, Town (Urban)-22 and Rural schools were a bit lower with 17. More than 20 schools which took part in the research chose not to indicate the level of their school. While in Area one the highest number of schools were from rural areas (8), in Area two the highest number of schools were from townships (22) and in Area three, townships and rural areas had the same number of schools ( 5 schools each).

As it can clearly be seen from Tables 3-5, there are no major differences between these three areas. Area one has the highest percentage of respondents who "strongly agree" in all the seven components compared to area two and three. However, the percentage of respondents who "agrees" in Area two and three is more than that in Area one by a similar margin in six of the core components. The similarities in the three areas is also seen from (1.) the percentages of those who "disagreed" or "strongly disagreed" in the three areas and in all the seven components, and (2.) the "supportive conditions-structures" which had the highest percentage of respondents who "disagree" in all the core components in the three areas.

Research question 2: How is teachers' and principals' perception of schools as PLCs in urban towns different from those in rural areas and townships? Our findings from this research reveal that teachers and principals' perception of schools as professional learning communities in urban towns, townships and rural areas were very different, especially comparing schools in urban towns with those in townships and rural areas. These differences were statistically significant very close to the medium effect size. If this perception is seen as school performance, the highest will be towns (urban), then rural areas and at the bottom townships.

These findings are in agreement with previous researchers like Gardiner [1] who explained that the South African Constitution, the South African School Act and other "education policy documents say that all South African learners should have access to the same quality of learning and teaching, similar facilities, and equal educational opportunities" but according to him this is not yet the 
case. Many schools and their rural areas still face problems of lack of good classrooms, limited or no access to water and electricity, limited school libraries, no internet, and poverty and unemployment, and these all have "direct influence[s] on the quality of education" [1]. Smith and Oosthuizen [22] have concluded that the South African education system still has some systemic weaknesses. According to them formal Model C schools (in urban areas are generally well-resourced and previously advantaged) are doing well and the current state funding education system favours these previous advantaged schools.

Education in townships also faces many challenges, like overcrowded classrooms, no access to computers, crime, student dropout, lack of facilities like laboratories and libraries, learner transportation and many teachers are suffering from stress which makes them more susceptible to bullying issues [23] [24] [25]. Ambrecht [23] believes that language is another problem. There are 11 South African languages and no pupil in a Black Township for example uses English as a home language. According to her it is not easy to get quality teachers in each of the indigenous languages. She also believes that townships have been marginalized.

Research question 3: How are teachers and principals in different types of schools (primary, combined etc.) different from each other in the perception of their schools as PLCs? Comparing teachers' and principals' perception of their schools as professional learning communities revealed that primary schools' perception is highest compared to combined, intermediate and secondary schools. What accounts for these disparities between various levels of schools?

Researchers have not agreed on why many pupils' performance drops as they progress to high school. McGee, Ward, Gibbons and Harlow [25] have claimed that at the lower levels (primary) children are not given challenging work and as such they pass their examinations and excises with excellent grades. According to this school of thought, as students' progress to high school, many changes take place like change in teaching methodology, a more challenging work load, preparation for national examination, demand for independent study skills and a challenging curriculum, among others. Roderick and Camburn [26] have attributed the drop in student performance to the fall in motivation and changes in learning environment as students' progress to high school. In South Africa, we will suggest that further research investigate the reasons for these differences in teachers' perception between primary and other levels of schools. Will the findings confirm with those from the United Kingdom and Australia as explained above or are there other underlying factors? Limitation of the study: This study was limited to three educational areas. It will be a good idea to repeat the same study in the whole Country and compare teachers and principals' perceptions between Provinces, Towns/Cities and Townships, and Towns/Cities and Rural Areas.

\section{Conclusions}

In order to understand the distinction between towns (urban), townships and 
rural areas, we need to understand the history of South Africa. Urban centres were whites' domain and townships were for blacks and coloured people (separated) and are usually located near urban centres [1]. These urban centres (cities and towns) are where formal white schools are located and it may help to explain why the schools in urban towns are still doing better than those in townships and rural areas, because they are favoured by the current state funding system [1]. Gardiner [1] believes that "a one size fits all policy... makes it possible to overlook and disregard important aspects of the lives and needs of communities" (townships and rural).

Our major findings are as follows: There were no major differences between schools in Area 1, 2 and 3 in all the core components. The perception of teachers and principals of schools in urban areas was much higher than those in townships and rural areas. This may actually be true when we examine the view that a current education state funding system has failed to address problems like facilities in rural areas and classroom size and crime in townships. Primary school teachers' and principals' perception of their schools as professional learning communities is higher compared to combined, intermediate and secondary schools with statistically significant medium effect sizes in a majority of the core components.

The study has also given us some realities of teachers' and principals' perception of their schools as professional learning community, for example the low perception of teachers and principals of township schools. Suggestion for further research: It will be a good idea to investigate the reasons for the low perception of teachers and principals of township schools. Is it that urban and rural schools are performing better than township schools? Or what are the underlying factors for this low perception? It will also be an excellent idea for further research to investigate the reasons for the high perception of primary school teachers and principals, compared with the much lower perception of high school teachers and principals for example.

\section{Acknowledgements}

We would like to thank the officials in the department of education, for giving us permission to carry out this research. We would also like to thank the Area Managers and other staff in their areas for facilitating the data collection process. Our immense thanks also goes to our research assistant for making phone calls to principals reminding them to return the questionnaires. The writing of this article was funded by North-West University, Potchefstroom, South Africa.

\section{References}

[1] Gardiner, M. (2008) Education in Rural Areas. Issues in Education Policy No. 4, Centre for Education Policy Development (CEPD).

http://www.cepd.org.za/files/CEPD_Issues_in_education_Education_in_rural_areas .pdf

[2] Nkengbeza, D., Pulkkinen, S. and Kanervio, P. (2015) Assessing Comprehensive Schools in One Finnish Municipality as Professional Learning Communities. Zim- 
babwe Journal of Science and Technology, 10, 69-84.

[3] DuFour, R. (1997) Functioning as Learning Communities Enables Schools to Focus on Student Achievement. Journal of Staff Development, 18, 56-57.

[4] DuFour, R. and Eacker, R. (2008) Revisiting Professional Learning Communities at Work: New Insights for Improving Schools. Solution Tree Press, Bloomington.

[5] Nkengbeza, D. (2014) Building a Professional Learning Community in a Conflict and Post-Conflict Environment: A Case Study of a High School in Liberia. University of Jyvaskyla Printing House, Jyväskylä.

[6] Hord, S.M. (2003) Professional Learning Communities: Communities of Continuous Inquiry and Improvement. Southwest Educational Development Laboratory, Austin.

http://www.pdfdrive.net/professional-learning-communities-welcome-to-sedl-adva ncing-e1879669.html

[7] Lee, C.K., Zhang, Z. and Yin, H. (2011) A Multilevel Analysis of the Impact of a Professional Learning Community, Faculty Trust in Colleagues and Collective Efficacy on Teacher Commitment to Students. Journal of Teaching and Teacher Education, 27, 820-830.

[8] Hord, S.M. (2009) Professional Learning Communities: Educators Work Together towards a Shared Purpose-Improve Student Learning, National Staff Development Council, 30, 40-43.

[9] Nkengbeza, D. (2016) School Leadership Role in a Conflict and Post-Conflict Environment School Reconstruction as a Professional Learning Community. Open Journal of Social Sciences, 4, 70-79. https://doi.org/10.4236/jss.2016.48009

[10] Nkengbeza, D. and Shava, G.N. (2016) A Survey of the Role of Shared Supportive Leadership in Creating Professional Learning Communities in Schools. International Journal of Innovative and Applied Research, 4, 45-52.

[11] Webb, R., Vulliamy, G., Sarja, A., Hamallainen, S. and Poikonen, P. (2009) Professional Learning Communities and Teacher Well-Being? A Comparative Analysis of Primary Schools in England and Finland. Oxford Review of Education, 35, 405-422. https://doi.org/10.1080/03054980902935008

[12] Vescio, V., Ross, D. and Adams, A. (2008) A Review of Research on the Impact of Professional Learning Communities on Teaching Practice and Student Learning. Journal of Teaching and Teacher Education, 24, 80-91.

[13] Huffman, J. (2003) The Role of Shared Values and Vision in Creating Professional Learning Communities. NASSP Bulletin, 87, 21-34. https://doi.org/10.1177/019263650308763703

[14] Hunter, J. (2013) Professional Learning Communities. http://johunter.pbworks.com/f/PLC.pdf

[15] Creswell, J.W. (2008) Education Research: Planning, Conducting, and Evaluating Qualitative and Quantitative Research. 3rd Edition, Pearson Education Inc., Cape Town.

[16] Best, J.W. and Kahn, J.V. (2006) Research in Education. 10th Edition, Pearson Education Inc., Cape Town.

[17] Olivier, D.F., Antoine, S., Cormier, R., Lewis, V., Minckler, C. and Stadalis, M. (2009) Assessing Schools as Professional Learning Communities' Symposium. Paper presented at the Annual Meeting of the Louisiana Education, Lafayette, Research Association.

[18] Hair, J.R., Anderson, R.E., Tatham, R.L. and Black, W.C. (1998) Multivariate Data Analysis. Prentice-Hall, Inc., New Jersey, 730 p. 
[19] Thompson, B. (1994) Guidelines for Constructors. Educational and Psychological Measurement, 54, 837-847.

[20] George, D. and Mallery, P. (2003) SPSS for Windows Step by Step: A Simple Guide and Reference. 4th Edition, Allyn and Bacon, Boston.

[21] Field, A. (2009) Discovering Statistics Using SPSS. 3rd Edition, SAGE Publications, London.

[22] Smit, M.H. and Oosthuizen, I.J. (2011) Improving School Governance through Participatory Democracy and the Law. South Africa Journal of Education, 31, 55-73.

[23] Ambrecht, J. (20014) Education Challenges in South African Township. BORGEN Magazine. http://www.borgenmagazine.com/education-south-africas-townships/

[24] Masitsa, M.G. (2011) Exploring Safety in Township Secondary Schools in the Free State Province. South African Journal of Education, 31, 163-174.

[25] Motseke, M.J. (2005) OBE: Implementation Problems in the Black Townships of South Africa. Interdisciplinary Journal, 4, 113-121.

[26] Roderick, M. and Cambum, E. (1996) Academic Difficulty during the High School Transition. In: Sebring, P., Bryk, A.S., Roderick, M. and Cambum, E., Eds., Charting Reform in Chicago: The Students Speak, The University of Chicago, Consortium on Chicago School Research, Chicago, 47-65. 
Appendixes

Professional Learning Communities Assessment Questionnaire

Instructions

Please read carefully the questionnaire below assessing your perception of your principal, staffs and other stakeholders in your educational institution as a professional learning community.

The purpose of this research is to determine how the teachers and principals perceive their school as a professional learning community. Please rate each statement on the scale below in terms of its relevance to practices within your school.

Section A: Personal Information (Please tick the correct box)

1. Gender

Male

Female

\section{Age Group}

Less than 35

Between 35 and 55

More than 55

3. My post in the school

Class Teacher (Gr 1 - 3)

Subject Teachers (Gr 4 - 12)

Head of department

Principal or Vice Principal

4. Level of school

\section{Primary}

Combined

Intermediate

Secondary

\section{School location}

$$
\text { Township }
$$

Town (Urban)

2

Rural (if not part of any of the above)
1

2

1

2

3

4

\section{2}


6. Number of learners in your school (for principals/vice principals only)

7. Number of teachers in your school(for principals/vice principals only)

Section B: SCALE: 1 = Strongly Agree (SA), $2=$ Agree (A), 3 = Disagree (D), and $4=$ Strongly Disagree (SD)

Shared and Supportive Leadership

1. Teachers are frequently involved in discussions and decision making about most teaching and learning issues

2. These discussions (mentioned in no 1 above) usually take place during meetings (e.g. staff meetings)

3. The principal incorporates advice from staff members to make decisions about school improvement

4. Teachers have access to key information (e.g. when to take professional training, discuss key issues affecting their school etc.)

5. The principal addresses areas where support is needed in teaching and learning

6. Opportunities are provided for teachers to suggest how their school can be improved

7. Heads of departments effectively support teachers

8. The principal shares responsibility in the school

9. The principal rewards teachers for innovative actions

10. The principal participates democratically with teachers in sharing power

11. Leadership among all teachers are promoted in the school

12. Leadership among all non-teaching staff are promoted in the school

13. Leadership among all learners are promoted in the school

14. Leadership among all parents are promoted in the school

15. Decision-making takes place through committees in the school

16. There is communication (formal or informal) across various areas in the school (e.g. grade and subject area interaction)

17. Stakeholders (e.g. parents, teachers, principal, community and the government) assume shared responsibility for the school

18. Teachers use multiple sources (e.g. different text books, internet sources, etc.) of data to make decisions about teaching and learning

COMMENTS

Please write behind this page if you need more space 
SCALE: $1=$ Strongly Agree (SA), $2=$ Agree (A), $3=$ Disagree (D), and $4=$ Strongly Disagree (SD)

\begin{tabular}{llllll}
\hline Collective Learning and Application & SA & A & D & SD \\
\hline
\end{tabular}

19. Teachers work together to seek new knowledge or skills

20. Teachers apply the new knowledge in their work

21. Heads of departments are part of the learning teams in the school

22. Collegial relationships exist among teachers

23. Teachers are committed to school improvement efforts

24. Teachers work together to search for solutions to address diverse learner needs (e.g. different reading abilities)

25. Different meetings (e.g. departmental or grade or subject meetings) exist where teachers can learn from each other

26. Teachers use the different meetings to learn from each other

27. Teachers actively discuss new ideas and problems affecting their school

28. Teachers and parents come together to discuss better ways to solve school problems

29. Teachers and broader community role players (e.g. business) come together to discuss better ways to solve school problems

30. All our staff members attend professional development organized by the Department voluntarily because we want to improve the quality of education

31. Teachers are committed to voluntarily come together and discuss issues that enhance learning

32. Teachers work together to read journals or books to learn about the effective teaching and learning methods

33. Teachers collaboratively analyze learner work to improve teaching and learning

COMMENTS:

Please write behind this page if you need more space

SCALE: 1 = Strongly Agree (SA), $2=$ Agree (A), 3 = Disagree (D), and $4=$ Strongly Disagree (SD) 
34. Teachers work together to develop shared values

35. Shared values guide decisions about teaching and learning

36. Teachers share a vision that has a firm focus on learner learning

37. The heads of departments play an important role to emphasise the values and how it link to our teaching and learning

38. Decisions are made in alignment with the school's values and vision

39. School goals focus more on learners issues (e.g. community values or citizenship) than test scores

40. Our shared values help us to work harder e.g. do professional development

41. School policies about discipline are aligned to the school's vision.

42. Teachers are actively involved in activities that increase learner achievement

43. Heads of departments lead by example to improve their own performance

COMMENTS:

Please write behind this page if you need more space

SCALE: $1=$ Strongly Agree (SA), $2=$ Agree (A), $3=$ Disagree (D), and $4=$ Strongly Disagree (SD)

\section{Shared Personal Practice}

SA A D SD

44. Opportunities exist for teachers to observe peers outside the institution quality management structure (IQMS) process

45. Teachers provide feedback to peers related to instructional practices

46. Teachers and principals informally share ideas or suggestions for improving learner learning

47. Teachers collaboratively review learner work to share and improve instructional practices

48. There is an official process for mentoring

49. Individual teachers have the opportunity to share the results of their practices with other individuals

50. Teachers and heads of departments informally share ideas or suggestions for improving learner learning

51. Our subject or phase is really working as a team have the opportunity to share the results of their practices

COMMENTS

Please write behind this page if you need more space 
SCALE: 1 = Strongly Agree (SA), $2=$ Agree (A), 3 = Disagree (D), and $4=$ Strongly Disagree (SD)

\begin{tabular}{llllll}
\hline Supportive Conditions-Relationships & SA & A & D & SD \\
\hline
\end{tabular}

52. Caring relationships exist between the teachers and learners that are built on trust and respect

53. A culture of trust and respect exists among teachers

54. Outstanding achievement is recognized or celebrated regularly in your school

55. Teachers exhibit a sustained and unified effort to embed change into the culture of the school.

56. My head of department have a good relation with all of us in the team

57. Parents and other stakeholders play a supportive role in the school

58. Relationships among the teachers is good enough to discuss test results to enhance teaching and learning

COMMENTS:

Please write behind this page if you need more space

SCALE: $1=$ Strongly Agree (SA), $2=$ Agree (A), $3=$ Disagree (D), and $4=$ Strongly Disagree (SD)

\begin{tabular}{lllll}
\hline Supportive Conditions-Structures & SA & A & D & SD \\
\hline
\end{tabular}

59. There is enough time during the official school hours for teachers to work together

60. Financial resources are available for professional development

61. Teachers in their departments have the opportunity to make recommendations to the SGB about the selection of new teachers

62. Appropriate technology is available to teachers

63. Teachers are supported by the school with instructional materials

64. There is available place for teachers to meet and discuss school issues

65. The school facility is conducive for learning

66. The HODs, (deputies) and principal function well as the school management team (SMT)

COMMENTS:

Please write behind this page if you need more space 
SCALE: $1=$ Strongly Agree (SA), $2=$ Agree (A), $3=$ Disagree (D), and $4=$ Strongly Disagree (SD)

\begin{tabular}{|c|c|c|c|c|}
\hline Other statements supporting PLCs development & SA & A & $\mathrm{D}$ & SD \\
\hline $\begin{array}{l}\text { 67. Heads of departments provides support for continuous } \\
\text { learning of teachers }\end{array}$ & & & & \\
\hline $\begin{array}{l}\text { 68. The proximity between teachers and department personnel } \\
\text { allows for ease in collaborating with colleagues }\end{array}$ & & & & \\
\hline $\begin{array}{l}\text { 69. Available communication systems promote a flow of } \\
\text { information among staff members }\end{array}$ & & & & \\
\hline $\begin{array}{l}\text { 70. Available communication systems promote a flow of } \\
\text { information across the entire school community including } \\
\text { central office personnel, parents, and community members. }\end{array}$ & & & & \\
\hline $\begin{array}{l}\text { 71. Data is organized and made available to provide easy } \\
\text { access to teachers }\end{array}$ & & & & \\
\hline COMMENTS: & & & & \\
\hline Please write behind this page if you need more space & & & & \\
\hline
\end{tabular}

Source: Olivier, Antoine, Cormier, Lewis, Minckler, \& Stadalis, (2009). NB This questionnaire was modified to fit the context of the study. Contact me if you would like to collaborate in research in your country with this questionnaire etc. Dr David Nkengbeza, drnkengbeza@hotmail.com; dnkengbeza@unam.na.

Submit or recommend next manuscript to SCIRP and we will provide best service for you:

Accepting pre-submission inquiries through Email, Facebook, LinkedIn, Twitter, etc. A wide selection of journals (inclusive of 9 subjects, more than 200 journals)

Providing 24-hour high-quality service

User-friendly online submission system

Fair and swift peer-review system

Efficient typesetting and proofreading procedure

Display of the result of downloads and visits, as well as the number of cited articles Maximum dissemination of your research work

Submit your manuscript at: http://papersubmission.scirp.org/

Or contact jss@scirp.org 